\title{
Curatorial Reflections on Print Rooms and Libraries
}

THE GENERAL RELATIONSHip between libraries and museums is simply too broad a subject for me to wrestle with, although I am very glad that Gerald Beasley in his article in this issue has done such an excellent job of it. I intend, therefore, to focus on something more immediately relevant to my position, namely the relationship between libraries and museum collections of prints, or print rooms. That relationship, as you might expect, is a very close one. Whatever else libraries may collectfrom musical instruments to eyeglasses to stuffed animals to other artifacts-and whatever else print rooms may have-from drawings to copper plates to sculpture multiples and so forth — at their core, even in this digital age, both collect printed matter. Historically, many print rooms started as library departments, like those at the Bibliothèque Nationale de France and the New York Public Library, or in conjunction with libraries, as at the British Museum. Occasionally, some libraries actually began as parts of print rooms, such as in the Fogg Art Museum at Harvard or the Hamburg Kunsthalle.

Of course, print rooms and libraries do not collect precisely the same things, but just how should we distinguish them? Shall we say that print rooms collect printed images and libraries collect printed texts? That would be too simplistic, because print rooms also collect texts and libraries also collect images. Yet there is a grain of truth here, as virtually no print rooms with which I am familiar collect printed texts without any images, and few libraries without print rooms collect images without any text.

The relationship between collections of prints and books is an intimate and extensive one for two reasons. Compared with other art collections-for example, collections of paintings or sculptures or even drawings-print collections, with very few exceptions, are typically much larger in the number of objects they contain. In this regard, they are like book collections. Consider a focused institution such as the one at which I work, the National Gallery of Art in Washington, D.C., which pro- 
fesses to limit its collecting to artworks of great aesthetic value and which therefore does not possess a vast range of political caricatures, documentary works, and so forth. At the Gallery, we have about 3,000 paintings, another 3,000 sculptures, but 12,000 drawings, and more than 62,000 prints-which is an example of how large print and drawing collections typically are in relation to other art museum collections.

Of course, these relatively larger collections in print rooms are considerably more complex because of their size, including a wide range of artists, styles, schools, historical periods, and subject matter. Consequently, print collections require a considerable breadth of knowledge to assess, understand, and appreciate. Because books are still the primary carriers of such knowledge, print collectors need and typically do have large collections of texts that they use to study and evaluate their collections. These are their reference books.

The intimate and extensive relationship between print rooms and books, however, is much more essential for another reason. That is because prints are simply printed images, and printed images can appear separately or individually, or as series or groups, either bound or unbound, either with or without texts. Historically, in fact, I believe that after 1460 - but certainly after 1470 - at least as many if not even more printed images, including fine artists' prints, were issued as bound series or as illustrations to texts in bound volumes, as were issued as separate sheets. Printed images issued in bound states remained in the majority into the twentieth century, at least until World War I and quite likely to 1960. Thus, if you seriously collect prints, with very few exceptions you necessarily collect prints in bound volumes or books.

A good example for me is Giovanni Battista Piranesi. He who was certainly one of the dozen greatest printmakers in Western history. If you have a print room that covers more than modern art, you will want it to have a good representation of Piranesi etchings. Of the thousand or so etchings he made, only one (his Catalogo delle opere) was issued as a separate or individual object. All of the others were issued in bound volumes. Employing the normal standards of quality for all prints, if you want fine quality Piranesis, then you should have the originals, not reproductions. You want early states or editions, not later restrikes. You want undamaged impressions in their original condition, not torn or bleached or foxed or repaired. Finally, "good original condition" ideally means as they were originally issued, which is to say, in bound volumes.

The above generalities are reflected in historical fact. All major print rooms include libraries of reference books and include prints in bound volumes or rare illustrated 
books. This is true internationally. For example, the Berlin Kupferstichkabinet has about 10,000 reference books in the print room and about 6,000 rare books in bound volumes, which it began collecting at the outset of its institutional history in 1831 under its director Friedrich Lippmann. In Dresden, there are about 8,000 reference books in the print room, and about 2,000 volumes of what we would call "rare books." This type of allocation started in the 1780s when the Elector of Saxony's collection was divided between the main Dresden library and the print room, with many of the books going to the print room.

This situation also holds true in our country. From its founding in 1896, the print room of the Boston Museum of Fine Arts (MFA) began collecting bound volumes, including both reference books and rare illustrated books, under the direction of its first curator, Sylvester Rosa Koehler. This practice, which continued throughout the twentieth century, is still ongoing. Today the MFA has about 5,000 rare volumes. The print room at New York's Metropolitan Museum has about 12,000 rare illustrated books. Collecting of volumes at the Metropolitan began, again, with its first curator of prints, William Ivins, in 1917, and continued under his successors, especially A. Hyatt Mayor. In 1929, the Metropolitan mounted a major exhibition surveying its collection of prints that included ninety-six works. More than a third of them were displayed in bound volumes or had been removed from them. At the National Gallery of Art, the "youngest" of the major independent art museums with a print room, there are about 3,000 rare volumes in the print room. The collection began with Joseph Widener's 1942 donation of his outstanding French 18thcentury illustrated books, which arrived within a year of the museum's opening in 1941 and even preceded the appointment of a print curator.

In an attempt to clarify the different types of relationships that exist between libraries and print rooms, I would like to propose a simple typology rather than distinctions based on definitions. Two categories are the most obvious ones. First, there are independent libraries that do not have print rooms, such as the Newberry (in Chicago) or the Peabody (in Baltimore). Second, there are museums that have reference libraries but no print room, such as the Smithsonian Museum of Natural History or Dumbarton Oaks (in Washington, D.C.), or the Museum of Science and Industry (in Chicago). In both of these categories, the relationship of the library to a print room can only be distant, including inter-institutional loans for consultation or for exhibitions.

Relationships become more nuanced and interesting with the introduction of two additional categories. The first includes independent libraries with print rooms created as sections of the library. The Bibliothèque Nationale, the Library of Congress, and the New York Public Library are examples of this type. The second 
category includes print rooms and libraries that developed as independent but affiliated sections of a single institution, like the British Museum. In each of these categories there are close relationships between print rooms and libraries.

Similar works by the same or comparable artists, especially in the same or like media, are best seen, studied, and appreciated together, side by side. There would be little point in taking, say, all Rembrandt etchings and dividing them so that the etchings of portraits are stored and studied in one department and the etchings of landscapes in another. Likewise, no purpose would be served by separating into different departments Rembrandt's religious and mythological etchings that were issued as separate prints from those that were issued in books. Unfortunately, however, in our present two categories, many institutions have evolved with just such divisions within their collections.

Many independent libraries created not only print rooms but also rare-book rooms. Books that contained original prints as illustrations were most often stored in the rare-book room, not in the print room. Even though, in many cases, print rooms and rare-book rooms were located close to one another-across the hall or on the same floor-the separation frequently brought about unfortunate consequences.

Major libraries almost inevitably grow larger. Space becomes a crucial problem. New buildings and storage facilities lead to the separation of the libraries' print rooms and rare-book rooms. This is not just a theoretical problem. It happened at the British Museum when the British Library separated and moved from Bloomsbury to Paddington, and at the Bibliothèque Nationale in Paris when the Site Mitterand was built. The result is that many artists' works are now unnaturally divided. Woodcuts by Albrecht Dürer that appear on separate sheets are kept in the prints and drawings collection at the original location, while the Dürer woodcuts that appear in bound volumes are now primarily housed across town at Paddington or at the new Site Mitterand, far down the Seine River. A proof sheet without lettering of the woodcut Dürer created for the title page of Willibald Pirckheimer's edition of Petrarch may be located in the print room, while the book containing the same woodcut title page but with the lettering is far away. Although it is possible to view them together by requesting temporary loans, the bureaucratic process required to do so is beyond the average visitor. For the print rooms at the British Museum and the Bibliothèque Nationale, there is a very bitter lesson to be learned from this: no print room should rely on an attached rare-book library always being there to supply the illustrated books that it and its patrons need.

The final category that I would like to consider is museum libraries in museums with print rooms. It is difficult to generalize about university museums that have 
both libraries and print rooms since they differ so much from each other, so, I will set that "subcategory" aside and focus instead on independent art museums that have both libraries and print rooms. These include, for example, the Boston $\mathrm{Mu}-$ seum of Fine Arts, the Metropolitan Museum of Art, the Art Institute of Chicago, the National Gallery of Art, and so forth. I have interviewed many curators, nationally and internationally, as well as librarians, to ensure that the remarks that follow are not too personal or idiosyncratic.

At these independent art museums, the museum libraries and print rooms share reference literature. This arrangement presents almost no difficulties. Yet, for the last decade or two, a number of curators have observed that some museum libraries appear to be expanding their collection range and territory into books as works of art. Curators have begun finding that this practice interferes with the collection of printed art in book form by the print rooms.

Consider some examples, from the uncontroversial to the more provocative. It seems clearly appropriate for art history libraries in museums to collect basic texts in art history even though some of those texts also have fine illustrations, the second edition of Vasari's Lives of the Painters, for example. No print room curator I know would ever object to such collecting. Further, I doubt that any curator would object to libraries collecting technical manuals that belong in art reference libraries, despite the fact that they may have fine-art illustrations. For instance, the first English edition of Alois Senefelder's book on lithography has a splendid lithograph by Samuel Prout. No curator, however, is going to be exercised because the work is kept in the reference library. Yet what of the 1868 edition of Hamerton's book on etching, which has an original Rembrandt etching, an original Whistler etching, and so forth? Where should that volume be housed? Or, the Dürer book on human proportions with numerous original Dürer woodcuts-is this a technical manual, or is it a fine art illustrated book?

With respect to city and country guides, we expect many or even most of those to be in an art history reference library. But some of these may have very fine illustrations, like the guide books to Rome that contain Piranesi etchings, or the great Abbé de Saint Non's Voyage Pittoresque de Naples et de Sicile, with illustrations after Fragonard and Robert. It seems inappropriate to say the Saint Non must be in the library when the print room may have original drawings or proof etchings for some of those illustrations, or other series of Saint Non prints that were issued without any type-printed texts. On the other hand, it is a disadvantage to the library if the print curator asserts that books like the Saint Non have to reside in the print room, which would suggest that the library was relegated to the old guidebooks that are visually dull or uninteresting, but that the beautiful ones belong in the print room. 
Emblem books pose an even greater problem than do art history texts or guidebooks. Are emblem books more appropriate for the art history reference library or for the print room? One librarian from a major institution says that they are clearly works of art and do not belong in the reference library but rather in the print room. At a different institution, the librarian says that not only do they belong in the library, but they are essential to the library's mission of providing research materials for art historians. For some years at the National Gallery, the chief librarian and I would try to decide on a case-by-case basis whether a book was important mainly for its reference value or its artistic value. Although a dull knife with which to slice the material apart, this was at least a cooperative approach.

Moving even further into the problem, what about classic rare illustrated books? Take, for example, a major architectural or archeological treatise, such as the first edition of Palladio in 1570, or the 1721 Fisher von Erlach, or Piranesi again. Where do these belong? Or what of the so-called ornament books that are suites of ornament prints with no type-printed texts: where do they belong? What about suites of prints that are urban and landscape views like the earliest extensive group of Roman views in the sixteenth century Speculum? The Avery Library has one. The National Gallery Print Room has one. It could be in the library, or it could be in the print room; a case can be made for either choice. But consider the suite of Hieronymus Cock etchings, his views of Rome. Although they are the next major group of views of Rome after the Speculum, they seem clearly to belong in the print room. And what of the works of Piranesi and his views of Rome: where do they belong? Or Giacometti's lithograph views of Paris? These are all the same kind of material, but in the latter cases, if the choice is available within a museum institution, they clearly belong not in an art history reference library but in a collection of fine artists' prints.

My final three categories of bound volumes are suites of prints on religious history or mythological history, early illustrated religious texts, and early illustrated literature, such as Dante, Virgil, Terence, or Ovid. To me, these works in an art museum seem absolutely to belong in the print room and not in the art history reference library, as I see a clear distinction between works of art and works of art historical reference material. But I know art history reference librarians who are buying books in just these categories, which is why print room curators are becoming concerned that their traditional and reasonable area of responsibility is being encroached upon by some museum librarians.

Museum librarians are intelligent people and have rationales for why they should pursue works of art for art history reference libraries. For example, although a bound volume is valuable primarily because of the traditional fine-art method of 
producing its illustrations and because of the aesthetic value of those illustrations, nonetheless some of its illustrations may have influenced a major artist represented in the museum's art collection. Because of that influence, it is an important work for art historians to consult in order to understand that artist, and therefore, a librarian might argue, it belongs as art historical reference material in the art history library. In his early etching of a "Lion Hunt," for example, Rembrandt used a composition taken from an etching by Antonio Tempesta, so that the volume of Tempesta's Hunting Scenes would be appropriate for the library to acquire as reference material for art historians to study Rembrandt's works and those of other artists. Yet what are the implications of such an argument? Rembrandt also used the engravings of Andrea Mantegna and Lucas van Leyden to formulate many of his compositions. Consequently, should the museum library acquire not just reproductions but also the originals of those prints? What about the drawings by other artists, or indeed Rembrandt's own preparatory drawings, which are so important for art historians to study and refer to in order to understand the development of Rembrandt's compositions? Or even the Titian and Raphael paintings that influenced Rembrandt's art? Should the library also collect these works of art as reference material for art historical study? Even the most aggressively expansive art librarian would probably not dream of going so far. For me, however, these examples show a reductio ad absurdum - or at least a warning of extreme caution - against using the original argument in an attempt to justify a museum library collecting works of art as reference material.

As a postscript, there is the special category of contemporary artists' books. One major museum's librarian with whom I spoke said, "I wouldn't touch them with a barge pole. They are clearly art. They have no art historical reference value.” I think he is absolutely right. Yet there are other museum librarians who are actively pursuing so-called artists' books, especially if they are available as gifts and-strangely enough-especially if they are not wanted by the print rooms. In one major institution, a donor annually gave money to support the purchase of artists' books. If the print room did not want to acquire a particular book, that is, if the curators did not think it was good enough as a work of art for the museum's print collection, they suggested to the librarian that he use the donor's money to buy such books for the library. In the case of another major museum, a collector who had a very substantial collection of artists' books offered them to the museum as a gift. The curator in charge of the area of modern prints and illustrated books surveyed the collection and decided that it was not of sufficient artistic value for the museum. A few months later, without consulting the curator of prints and drawings, the librarian accepted that same collection as a gift for the museum library. This seems inappropriate to me because it implies that the library is making curatorial decisions over what is clearly art, and judging whether it is good art or not. Even worse, in 
both of these cases, the libraries are acquiring art that the professional art curators employed by the museums do not think is up to the standards of their institutions.

From the curatorial point of view, I hope you can see why, in these examples, there is cause for some concern. If museum librarians flirt with and, to some extent, expand their focus from what is good art historical research material, to collecting works of art that happen to be in bound volumes, it could result in their letting the collecting and caring for research materials "float along," because order systems are set up to keep buying monographs and periodicals, to keep getting standard works from book dealers and others. As one distinguished curator in another print room, who is also the president of one of our curatorial organizations, said to me, "Whether we look at museum education departments or museum development departments or museum libraries, we see more and more that everybody wants to play at being a curator."

I have some explanations for this development, but I will instead go directly to my conclusion: what difference does it make? What are the advantages or disadvantages for the institution if the library proceeds to collect art books? Why should a museum library collect only rare illustrated books, and not suites of prints-even single artists' prints - and also albums and sketchbooks and even oil sketches? After all, can they not be considered research materials?

On the plus side, the institution can acquire more art if additional funds are raised for library acquisitions. If funds are diverted from art funds, the museum does not get more art; rather, it gets different art. Also, if more staff are choosing art for the institution, it could result in more diversity, a greater richness, in the collections.

On the downside, there are two issues raised by curators that, in the end, I do not think need to be problems. First is the possibility that the collecting of art by the museum library creates conflicts between the missions or programs of different divisions in the institution. I hear this from many of my print curator colleagues. However, I believe that this is an internal matter for the institution, and it is solvable, at least partially, with consultation and compromise. Departmental mission statements matter little to the outside world. Secondly, many curators have also said that if multiple representatives for the institution are speaking with different voices about the same artistic issues, it is confusing for those outside the institution. But the reality is that outsiders rarely know the internal lines of authority in an institution, so it is very unlikely that they are confused. I do know that book dealers can become confused if they do not know where to offer a particular rare illustrated art book, or if they receive multiple orders for the same book from different departments in the same institution. Yet I do not think this is a big enough problem to warrant a change in collecting policy. 
A more important problem is that if libraries also collect art, then the works may not be in their most useful proximity for study and appreciation. If ninety percent of the Dürer woodcuts are in the print room, but ten percent are in the library, then they are not integrated and are not seen or studied side-by-side. This is a less of a problem if the print room can make arrangements to borrow such artists' prints and bound volumes from the library on a regular basis. But if for some reason the library will not cooperate with such internal loans, then there is a much more serious problem. I understand this is an issue at one of our oldest northeastern universities. This is also the situation with the Bibliothèque Nationale and the British Museum, where the consequences of physical divorces are hard to overcome. If that kind of system is permitted to develop in an institution, there is always a possibility that the different parts of the institution will become even more distant in the future.

A second major problem occurs when similar or even the same works of art are collected by both the library and the print room. There are extensive provisions for works of art in the museum's art collections for their safety, preservation, and careful legal handling. Yet what about the very same works of art if they are kept in the library? A work must be vetted as to provenance and export, and legal warranties signed by the dealer if purchased by the print room; not so if purchased by the library. The same work can be studied by a visitor only under direct visual supervision if in the print room; not necessarily so if in the library. The work can be conserved only with written proposals and multiple signatures by appropriate professionals if it is in the print room; not so if in the library. It can only be lent with multiple approvals, including that of the trustees, if in the print room; not so if in the library. It cannot be exhibited in daylight, or high artificial light, if in the print room; not necessarily so if in the library. The very same work can be deaccessioned only with multiple approvals, including that of the trustees, if in the print room; not so if in the library. Of course, an easy solution to these anomalies would simply be to bring all the works of art in the library under the same rules as those in the print room, but to me this seems unlikely to be welcomed by librarians and shows these anomalies really need a different administrative or managerial solution.

In my opinion, the most serious problem remains the diversion of resources in the museum. If art history reference libraries are complete with all the important reference material, and if no further important or interesting art historical reference material is available for that library, then it is difficult to find fault with using library resources to collect art. But if the library diverts resources from interesting and important reference material to pursue adventures in rare art books, that, in my opinion, represents a dangerous wandering from the library's core mission. 
One of the distinguished museum librarians we have had at the National Gallery has said that it is crucial for the library to widen its scope constantly to get more original reference materials: monographs, periodicals, auction catalogues, and so forth. As for the classic art books - the Palladio and the Dürer-most are available in facsimile, and the facsimile is perfectly fine for art historical research. The next great target for research libraries, he went on to say, is art historians' research materials and papers.

This introduces a truly complex issue. We know that, in the case of great art historians like Wittkower and Panofsky, their families or their followers have been through most of their papers, and much of what they did not publish in their lifetimes has been published after their deaths. Yet that still leaves a vast range of primary material from other scholars. Think about the number of PhDs awarded in art history where the recipients became serious authorities on important subjects and collected much valuable material in visual and written form. What happens to that material? To take just one rare-book-library example: a dear friend, Eleanor Garvey at the Houghton Library, has worked for decades on a catalog of the great and extensive eighteenth-century Italian illustrated books held by her library. She has extensive notes, well-researched and annotated cards on each book, innumerable perceptive comments, analyses, and comparisons. But if she does not finish that project, what is going to happen to that material? What should happen to it? Is it not prime material for art historical consultation and research?

On the other hand, another museum librarian has told me that it is much more important to him to get the original art books. He feels the library needs the Palladio, needs the Dürer in the original not just in facsimilie. Asked about art historical research materials, or auction catalogues, he replies that beyond what his library has old auction catalogues have become so expensive now, they are so hard to find, and they are all available on microfiche. As for the art historians' research materials and papers, they are just too complicated and expensive to catalog and make available. I cannot agree with such views. For me, as a researcher, there is no comparison between old reference books and original auction catalogues, and such material on microfiche. There is no comparison in utility for my research. With provenance posing such an enormous problem for all of us, having the best materials for provenance research becomes especially crucial. This is the real difficulty with museum libraries expanding into collecting art books: such collecting inevitably diverts resources and attention from other library needs, including enhancing the core collection of research material and solving problems with the complicated but enormous potential research value of art historians' archives. This is why it seems to me, and to many of my curatorial colleagues, wrong in policy as well as in practice. 